\title{
Positive Number
}

National Cancer Institute

\section{Source}

National Cancer Institute. Positive Number. NCI Thesaurus. Code C113772.

A quantity having a value greater than zero. 